\title{
Cocaine-Induced Chromatin Remodeling Increases Brain-Derived Neurotrophic Factor Transcription in the Rat Medial Prefrontal Cortex, Which Alters the Reinforcing Efficacy of Cocaine
}

\author{
Ghazaleh Sadri-Vakili, ${ }^{1}$ Vidhya Kumaresan, ${ }^{2}$ Heath D. Schmidt, ${ }^{3}$ Katie R. Famous, ${ }^{2}$ Prianka Chawla, ${ }^{2}$ Fair M. Vassoler, ${ }^{3}$ \\ Ryan P. Overland, ${ }^{1}$ Eva Xia, ${ }^{1}$ Caroline E. Bass, ${ }^{4}$ Ernest F. Terwilliger, ${ }^{5}$ R. Christopher Pierce, ${ }^{3}$ and Jang-Ho J. Cha ${ }^{1}$ \\ ${ }^{1}$ MassGeneral Institute for Neurodegenerative Disease, Massachusetts General Hospital and Harvard Medical School, Boston, Massachusetts, 02129-4404, \\ ${ }^{2}$ Department of Pharmacology, Boston University School of Medicine, Boston, Massachusetts 02118, ${ }^{3}$ Center for Neurobiology and Behavior, Department of \\ Psychiatry, University of Pennsylvania School of Medicine, Philadelphia, Pennsylvania 19104, ${ }^{4}$ Department of Pharmacology and Physiology, Wake Forest \\ University School of Medicine, Winston Salem, North Carolina 27157, and ${ }^{5}$ Division of Experimental Medicine, Harvard Institutes of Medicine, Beth Israel \\ Deaconess Medical Center and Harvard Medical School, Boston, Massachusetts 02115
}

Cocaine self-administration alters patterns of gene expression in the brain that may underlie cocaine-induced neuronal plasticity. In the present study, male Sprague Dawley rats were allowed to self-administer cocaine $(0.25 \mathrm{mg} /$ infusion $) 2 \mathrm{~h} / \mathrm{d}$ for $14 \mathrm{~d}$, followed by $7 \mathrm{~d}$ of forced abstinence. Compared with yoked saline control rats, cocaine self-administration resulted in increased brain-derived neurotrophic factor (BDNF) protein levels in the rat medial prefrontal cortex (mPFC). To examine the functional relevance of this finding, cocaine self-administration maintained under a progressive ratio schedule of reinforcement was assessed after short hairpin RNA-induced suppression of BDNF expression in the MPFC. Decreased BDNF expression in the mPFC increased the cocaine self-administration breakpoint. Next, the effect of cocaine self-administration on specific BDNF exons was assessed; results revealed selectively increased BDNF exon IV-containing transcripts in the mPFC. Moreover, there were significant cocaine-induced increases in acetylated histone $\mathrm{H} 3$ $(\mathrm{AcH} 3)$ and phospho-cAMP response element binding protein (pCREB) association with BDNF promoter IV. In contrast, there was decreased methyl-CpG-binding protein 2 (MeCP2) association with BDNF promoter IV in the MPFC of rats that previously selfadministered cocaine. Together, these results indicate that cocaine-induced increases in BDNF promoter IV transcript in the mPFC are driven by increased binding of $\mathrm{AcH} 3$ and $\mathrm{pCREB}$ as well as decreased MeCP2 binding at this BDNF promoter. Collectively, these results indicate that cocaine self-administration remodels chromatin in the $\mathrm{MPFC}$, resulting in increased expression of BDNF, which appears to represent a compensatory neuroadaptation that reduces the reinforcing efficacy of cocaine.

\section{Introduction}

Repeated intake of drugs of abuse, such as cocaine, promotes alterations in gene expression that underlie addiction as well as compensatory neuroadaptations (Wise, 2004; Kalivas, 2005; Nestler, 2005; Shaham and Hope, 2005; Pierce and Kumaresan, 2006). The most relevant of these cocaine-induced changes in gene expression occur in the ventral tegmental area (VTA), a major locus of dopamine neurons, as well as nuclei receiving dopaminergic

Received May 6, 2010; revised June 28, 2010; accepted July 11, 2010.

This work was supported by National Institute on Drug Abuse Grants DA22339, DA18678 (R.C.P.), DA017543 and DA024763 (C.E.B.), and DA18333-02 (E.F.T.) and the Glendorn Foundation (J.-H.J.C.). K.R.F. was partially supported by National Institutes of Health (NIH) National Research Service Award (NRSA) F30 DA19304, as well as NIH Training Grant T32 GM008541-7. H.D.S. was also partially supported by NIH NRSA Award DA16824. We thank Dr. Caroline Benn for valuable discussions.

Correspondence should be addressed to Ghazaleh Sadri-Vakili, MassGeneral Institute for Neurodegenerative Disease, Massachusetts General Hospital, 114 16th Street, Charlestown, MA 02129-4404. E-mail: gsadrivakili@partners.org.

DOI:10.1523/JNEUROSCI.2328-10.2010

Copyright $\odot 2010$ the authors $\quad 0270-6474 / 10 / 3011735-10 \$ 15.00 / 0$ inputs from the VTA, including the medial prefrontal cortex (mPFC), nucleus accumbens, and amygdala. A growing body of evidence indicates that cocaine alters the expression of neurotrophic factors. For example, previous studies have shown that an acute injection of cocaine increases brain-derived neurotrophic factor (BDNF) mRNA in the striatum, mPFC, and nucleus accumbens (Le Foll et al., 2005; Liu et al., 2006; Berglind et al., 2007). Similarly, a sensitizing regimen of cocaine injections or cocaine self-administration results in increased BDNF mRNA in the nucleus accumbens and striatum (Le Foll et al., 2002; Zhang et al., 2002; Kumar et al., 2005; Graham et al., 2007).

There are functional consequences of increases in BDNF transcription in various limbic nuclei. Three once-daily microinjections of BDNF into the VTA progressively augments BDNFinduced behavioral hyperactivity (Pierce et al., 1999). Moreover, continuous infusion of BDNF into the VTA or substantia nigra enhances the behavioral hyperactivity induced by an acute injection of cocaine (Martin-Iverson et al., 1994; Martin-Iverson and Altar, 1996; Horger et al., 1999). Repeated administration of 
BDNF into the nucleus accumbens augments the reinstatement of cocaine seeking (Graham et al., 2007). In addition, the timedependent increases in cue-induced cocaine seeking is paralleled by increases in BDNF levels in the VTA, nucleus accumbens, and amygdala over the first $90 \mathrm{~d}$ after cocaine self-administration (Grimm et al., 2003). Together, these results indicate that alterations in BDNF transcription in limbic nuclei have differential effects on cocaine-induced behavioral plasticity, including the reinstatement of cocaine seeking.

Recently, it was shown that exogenous BDNF infusions into the $\mathrm{mPFC}$ attenuate the reinstatement of cocaine seeking (Berglind et al., 2007, 2009; McGinty et al., 2010). Here, we report that cocaine self-administration increased BDNF protein and mRNA levels in the mPFC. To determine the functional relevance of this finding, the influence of viral-mediated decreases of BDNF levels in the MPFC on cocaine self-administration maintained under a progressive ratio (PR) schedule of reinforcement was evaluated. In addition, chromatin immunoprecipitation (ChIP) was used to identify the molecular mechanisms underlying the increase in BDNF mRNA in the $\mathrm{mPFC}$ associated with cocaine self-administration.

\section{Materials and Methods}

Animals and housing. Male Sprague Dawley rats (Rattus norvegicus) weighing 250-300 g were obtained from Taconic Farms. Animals were individually housed with food and water available ad libitum. A $12 \mathrm{~h}$ light/dark cycle was used with the lights on at 7:00 A.M. All experimental procedures were performed during the light cycle. A total of 107 rats were used in this study.

Surgery. Before surgery, the rats were anesthetized with $80 \mathrm{mg} / \mathrm{kg}$ ketamine and $12 \mathrm{mg} / \mathrm{kg}$ xylazine intraperitoneally. An indwelling Silastic catheter was placed into the right jugular vein (side opposite the heart) and sutured in place. The catheter was routed to a screw-on mount (Plastics One) that was sutured below the skin between the shoulder blades. The catheters were sealed with plastic obturators when not in use. After catheter implantation, some rats were mounted in a stereotaxic apparatus (David Kopf Instruments), and a viral vector ( $2 \mu \mathrm{l} /$ side) was administered at the borders between the infralimbic/prelimbic cortices $[+2.5 \mathrm{~mm}$ anteroposterior $(\mathrm{A} / \mathrm{P}), \pm 0.5 \mathrm{~mm}$ mediolateral $(\mathrm{M} / \mathrm{L})$, and $\pm 4.5 \mathrm{~mm}$ dorsoventral $(\mathrm{D} / \mathrm{V})]$ and prelimbic cortex/anterior cingulate $(+2.5 \mathrm{~mm} \mathrm{~A} / \mathrm{P}, \pm 0.5 \mathrm{~mm} \mathrm{M} / \mathrm{L}$, and $\pm 3.0 \mathrm{~mm} \mathrm{D} / \mathrm{V})$ via 33 gauge cannulae. All coordinates were relative to bregma according to the atlas of Paxinos and Watson (1997). Thus, each rat was microinjected with a $4 \mu \mathrm{l}$ of virus bilaterally into the infralimbic cortex, prelimbic cortex, and anterior cingulate, which collectively form the mPFC in the rat. Each $2 \mu \mathrm{l}$ microinjection was made over $10 \mathrm{~min}$, and the microinjector was left in place for 2 min after the infusion.

Self-administration training. After a 10-14 d [for short hairpin RNA (shRNA)] or $7 \mathrm{~d}$ (all other experiments) recovery period from surgery, the rats were placed in operant chambers and allowed to lever press for intravenous cocaine infusions $(0.25 \mathrm{mg}$ of cocaine $/ 56 \mu \mathrm{l}$ of saline per infusion over $5 \mathrm{~s}$ ) for $14 \mathrm{~d}$. Rats initially were trained using a fixed ratio (FR1) schedule of reinforcement with each daily self-administration session initiated by an intravenous priming injection of cocaine $(0.25 \mathrm{mg})$. When the animals achieved stable responding with the FR1 schedule (i.e., $<15 \%$ variation in response rates over 3 consecutive days), they were switched to an FR5 schedule for 14 consecutive days of self-administration. A 60 s timeout period during which responses have no scheduled consequences followed each cocaine infusion. The rats were limited to a maximum of 30 cocaine infusions per daily $2 \mathrm{~h}$ self-administration session.

Progressive ratio. For those animals in cocaine reinforcement experiments (using the progressive ratio schedule), when stable responding with the FR 5 schedule was achieved, as defined by a $<15 \%$ change in the number of responses on 2 consecutive days, the rats were switched to a progressive ratio schedule of reinforcement. The progressive ratio schedule is based on that of Richardson and Roberts (1996). The response requirement for the $i$ th reinforcement was given by $R(i)=\left[5 e^{0.2 \mathrm{i}}-5\right]$, where the brackets indicate the rounding function. Using this exponen- tial function, the response requirement for the first 10 injections was as follows: 1, 2, 4, 6, 9, 11, 15, 19, 25, 31 (etc.). Thus, under a PR schedule, the response requirement for each subsequent drug delivery increased until the subject failed to meet a requirement. The session expired when an animal took more than $1 \mathrm{~h}$ to receive an injection. The breakpoint was operationally defined as the number of cocaine infusions administered before the termination of the session.

Adeno-associated viral cloning and packaging. The enhanced green fluorescent protein (EGFP)-U6-pACP plasmid contains adeno-associated viral 2 (AAV2) inverted terminal repeats flanking a cytomegalovirus promoter, the coding sequence for EGFP, an intron and polyadenylation signal derived from simian virus 40 , and, further downstream, a murine U6 pol III promoter. To obtain each AAV-shRNA, synthetic oligos encoding the shRNA and its respective complement (Integrated DNA Technologies) were annealed and ligated into unique BbsI and NheI sites in the AAV plasmid downstream of the U6 promoter. The BDNF mRNA target sequence used, ACCATAAGGACGCGGACTTGT (from National Center for Biotechnology Information reference sequence NM_012513), was selected after in vitro screening of multiple candidates (C. E. Bass and E. F. Terwilliger, unpublished observations). Control vectors included AAV10 encoding either EGFP alone or AAV10 encoding EGFP plus a scrambled shRNA (CTGTTACGCTGGCTCTATCGA), which does not correspond to any known rat mRNA sequence. Packaging of all AAV was performed using a standard triple transfection protocol to generate helper virus-free pseudotyped AAV10 virus (Xiao et al., 1998). An AAV2/10 rep/cap plasmid provided AAV2 replicase and AAV10 capsid functions (Gao et al., 2002; De et al., 2006), whereas adenoviral helper functions were supplied by the pHelper plasmid (Stratagene). Briefly, AAV-293 cells were transfected with 1.33 pmol of pHelper and 1.15 pmol each of AAV2/10 and the shRNA-AAV vector plasmids, via calcium phosphate precipitation. The cells were harvested $48 \mathrm{~h}$ later, and the pellets were resuspended in DMEM, freeze thawed three times, and centrifuged to produce a clarified viral lysate. The vector stocks were titered by real-time PCR using the ABI Prism 7700 Sequence Detection System from PerkinElmer Applied Biosystems as described previously (Clark et al., 1999). The average titer of the preparations was $\sim 1 \times 10^{12}$ vector genomes/ml.

Immunohistochemistry. Ten days after rats received unilateral microinjections with AAV-viral vector containing EGFP-linked scrambled or EGFP-linked BDNF shRNA, animals were perfused with Formalin, and brains were postfixed in $10 \%$ Formalin for $24 \mathrm{~h}$ and then cryoprotected in sucrose before freezing at $-80^{\circ} \mathrm{C}$. Sections, $40 \mu \mathrm{m}$, were obtained using a cryostat and stored in a solution of $7 \%$ sucrose $/ 20 \%$ ethylene glycol in 0.1 M PBS. For BDNF immunohistochemistry, free-floating sections were washed in $0.1 \mathrm{M}$ PBS for $1 \mathrm{~h}$. Antigen retrieval was performed by heating sections in $10 \mathrm{~mm}$ sodium citrate, $\mathrm{pH} 6.0$, at $80^{\circ} \mathrm{C}$ for $15 \mathrm{~min}$. The sections were permeabilized in $0.5 \%$ Triton X-100 for $20 \mathrm{~min}$ and then incubated with $10 \%$ normal goat serum for $1 \mathrm{~h}$ before overnight incubation at $4^{\circ} \mathrm{C}$ with a 1:250 dilution of anti-BDNF polyclonal antibody (ab1779; Millipore Bioscience Research Reagents) prepared in $1 \times$ GDB buffer $(1 \%$ gelatin solution, $5 \%$ Triton X-100). After washing in $0.5 \%$ Triton X-100 for $1 \mathrm{~h}$, sections were incubated in a 1:1000 dilution of cyanine 3 goat antirabbit IgG in $1 \times$ GDB for $1 \mathrm{~h}$ at room temperature. Sections were washed in $0.1 \mathrm{M}$ PBS for $1 \mathrm{~h}$ and mounted with Vectashield (Vector Laboratories). BDNF immunoreactivity and GFP expression were examined with an Olympus BX60 fluorescence microscope, images were acquired, and intensity of staining was measured using NIH ImageJ software.

Western blotting. For Western blot analysis, histone extracts from dissected rat $\mathrm{mPFC}$ were used, and the experiments were performed as described previously (Sadri-Vakili et al., 2007). Briefly, mPFC from both hemispheres of a cocaine or yoked rat was homogenized in $200 \mu$ lof lysis buffer [1\% Nonidet P-40, $20 \mathrm{~mm}$ Tris, $\mathrm{pH} 8.0,137 \mathrm{~mm} \mathrm{NaCl}, 10 \%$ glycerol, $1 \mathrm{~mm}$ PMSF, sodium butyrate $1 \mathrm{~mm}$, and protease inhibitors (PIs)] at $4^{\circ} \mathrm{C}$. After removal of cellular debris by centrifugation, the supernatant was collected, and protein levels in the lysates were measured by the Bradford assay (Bio-Rad). Ten to $20 \mu \mathrm{g}$ of each sample was boiled in the presence of sample buffer for $5 \mathrm{~min}$ before separation on 10-20\% SDSpolyacrylamide gel, and proteins were transferred to nitrocellulose membranes. The immunoblots were blocked with $5 \%$ nonfat dry milk 
dissolved in Tris-buffered saline containing $0.2 \%$ Tween 20 (TBST) for 60 $\mathrm{min}$. The membranes were then incubated overnight at $4^{\circ} \mathrm{C}$ with specific antibodies that included the following: anti-di acetyl lysine 9 and lysine 14 histone $\mathrm{H} 3$ (AcH3) antibody (Millipore Corporation) at a dilution of 1:1500, anti-histone H3 antibody (Millipore Corporation) at a dilution of 1:500, anti- phospho-cAMP response element binding protein (pCREB) (Abcam) at a dilution of 1:500, and anti-methyl-CpG-binding protein 2 (MeCP2) (Abcam). Primary antibody incubation was followed by six washes (10 min, rocking, room temperature) in TBST before incubation with the secondary antibody (HRP-conjugated goat anti-rabbit IgG; Jackson ImmunoResearch), six washes, and visualization using the ECL detection system (PerkinElmer Life and Analytical Sciences).

ELISA. Ten days after rats received unilateral microinjections in the medial prefrontal cortex with AAV10 vector containing EGFP-linked shRNA targeting BDNF, four animals were killed, and bilateral medial prefrontal cortices were dissected. Tissues were lysed and homogenized and diluted to 10 and $20 \mu \mathrm{g} / \mu \mathrm{l}$. The concentration of BDNF in the diluted lysates was quantified using the ChemiKine Brain Derived Neurotrophic Factor (BDNF) Sandwich ELISA kit (catalog \#CYT306; Millipore Bioscience Research Reagents). The brain tissue samples and serial dilutions of BDNF standards were loaded in triplicate onto a microplate coated with rabbit anti-human BDNF polyclonal antibodies and incubated overnight at $4^{\circ} \mathrm{C}$. After four washes, biotinylated mouse antihuman BDNF monoclonal antibody (1:1000) was added to the microplate for $2.5 \mathrm{~h}$ at room temperature. The plates were washed four times and the streptavidin-enzyme conjugate was added to the plate and allowed to incubate for $1 \mathrm{~h}$. After additional washing, tetramethylbenzidine chromagenic substrate was added, and then 15 min later the reaction was stopped. The absorbance at $450 \mathrm{~nm}$ was measured with a plate reader. BDNF concentration in the brain tissue samples was measured by comparing values with the prepared standard curve.

Chromatin immunoprecipitation assay. We have adapted the ChIP technique to the analysis of brain tissue and have recently published detailed methodology for performing ChIP experiments (Braveman et al., 2004; Chen-Plotkin et al., 2006: Sadri-Vakili et al., 2007). Briefly, $\mathrm{mPFC}$ from both hemispheres of an individual cocaine or yoked rat was cut into pieces, and the pieces were weighed $(<30 \mathrm{mg})$ and deposited into tubes. Formaldehyde was added ( $10 \mu \mathrm{l}$ of $1 \%$ formaldehyde to $1 \mathrm{mg}$ of tissue), and brain pieces were incubated for $10 \mathrm{~min}$ at $37^{\circ} \mathrm{C}$ to cross-link DNA to associated proteins. Brain tissue was washed twice with ice-cold PBS containing PIs (Complete Mini protease inhibitor cocktail tablets; Roche) and then suspended in SDS lysis buffer (1\% SDS, 10 mM EDTA, and $50 \mathrm{~mm}$ Tris- $\mathrm{HCl}, \mathrm{pH} 8.1$ ) containing PIs at a ratio of $10 \mu \mathrm{l}$ of buffer for each milligram of brain. After incubating on ice for $10 \mathrm{~min}$, brain lysates were sonicated to shear lengths of 200-1000 bp DNA fragments using 10 sets of $10-15$ s pulses at setting 3 of a sonicator (Branson Cell Disruptor 350). We have found that this regimen yields DNA fragments appropriate for ChIP (200-1000 bp) (Braveman et al., 2004). The resulting homogenates from one brain were pooled and then centrifuged for 10 $\min$ at $13,000 \times g$ at $4^{\circ} \mathrm{C}$ to remove debris, and $200 \mu \mathrm{l}$ aliquots of the suspension were placed into separate sample tubes. Each sample was diluted tenfold with ChIP dilution buffer (0.01\% SDS, 1.1\% Triton X-100, $1.2 \mathrm{~mm}$ EDTA, $16.7 \mathrm{~mm}$ Tris-HCl, pH 8.1, and $167 \mathrm{~mm} \mathrm{NaCl}$ ), and $20 \mu \mathrm{l}$ (1\%) of the diluted sample was set aside and designated "Input" DNA. Samples were then either processed immediately or stored at $-80^{\circ} \mathrm{C}$.

For immunoprecipitation (IP), $2000 \mu \mathrm{l}$ of each sample was precleared with $80 \mu \mathrm{l}$ of salmon sperm DNA/protein A-agarose 50\% slurry (Millipore Corporation) by incubating at $4^{\circ} \mathrm{C}$ for $30 \mathrm{~min}$ with gentle agitation before overnight incubation $\left(4^{\circ} \mathrm{C}\right)$ with $5 \mu \mathrm{g}$ of each of the following antibodies: pCREB, MeCP2, AcH3, or 5-methyl-cytosine (Millipore Corporation). Negative controls included no antibody mock and IgG (Jackson ImmunoResearch). Mock immunoprecipitation conditions (mouse IgG) were also included as a control. After immunoprecipitation, $80 \mu \mathrm{l}$ of the salmon sperm DNA/protein A-agarose $50 \%$ slurry was added to samples, and immunocomplexes were collected for $1 \mathrm{~h}$ at $4^{\circ} \mathrm{C}$ on a rocking platform. After pelleting agarose (1000 rpm, $\left.4^{\circ} \mathrm{C}, 2 \mathrm{~min}\right)$, the chromatin-antibody/protein A-agarose complexes were washed sequentially ( 4 min each on a rotating platform) with $1 \mathrm{ml}$ each of the following: a low-salt buffer $(0.1 \%$ SDS, $1 \%$ Triton X-100, 2 mM EDTA, 20 mM
Tris-HCl, pH 8.1, and $150 \mathrm{~mm} \mathrm{NaCl}$ ), a high-salt buffer (0.1\% SDS, $1 \%$ Triton X-100, 2 mm EDTA, $20 \mathrm{~mm}$ Tris-HCl, pH 8.1, and $500 \mathrm{~mm} \mathrm{NaCl}$ ), an $\mathrm{LiCl}$ buffer $(0.25 \mathrm{M} \mathrm{LiCl}, 1 \% \mathrm{NP}-40,1 \%$ deoxycholate, 1 mM EDTA, and $10 \mathrm{~mm}$ Tris-HCl, $\mathrm{pH} 8.1$ ), and a TE buffer (10 mm Tris-HCl, $1 \mathrm{~mm}$ EDTA, pH 8.0). Elution was performed by incubation in $250 \mu \mathrm{l}$ of freshly made elution buffer ( $1 \%$ SDS, $0.1 \mathrm{M} \mathrm{NaHCO}_{3}$ ) for $15 \mathrm{~min}$ at room temperature; elution was repeated and eluates were combined. Crosslinks were then reversed by addition of $20 \mu \mathrm{l}$ of $5 \mathrm{M} \mathrm{NaCl}$ to the pooled eluates and heating of the mixture to $65^{\circ} \mathrm{C}$ for $4 \mathrm{~h}$. The saved input DNA was diluted to a volume of $500 \mu \mathrm{l}$ with sterile water, and cross-link reversal was performed in the same manner as for the ChIP samples. After cross-link reversal, all samples (ChIP and Input) were digested with $20 \mu \mathrm{g}$ of proteinase $\mathrm{K}\left(1 \mathrm{~h}, 45^{\circ} \mathrm{C}\right)$, and DNA was recovered with phenol/ chloroform extraction and ethanol precipitation. DNA pellets were resuspended in $25 \mu \mathrm{l}$ of sterile water.

One microliter ( 1 or $4 \mu \mathrm{l}$ for human samples) of ChIP-derived DNA was used as template in $20 \mu \mathrm{l}$ reactions containing $10 \mu \mathrm{l}$ of $2 \times$ SYBR Green Master Mix (Applied Biosystems) and $0.5 \mu \mathrm{M}$ of each primer. Real-time thermal cycling was performed using an iCycler thermal cycler (Bio-Rad), with continuous SYBR Green monitoring according to the recommendations of the manufacturer, using iCycler software. Cycling parameters for all amplifications were as follows: 60 cycles of $95^{\circ} \mathrm{C}$ for $30 \mathrm{~s}, 57^{\circ} \mathrm{C}$ for $30 \mathrm{~s}$, and $72^{\circ} \mathrm{C}$ for $45 \mathrm{~s}$, followed by melt-curve analysis $\left(55^{\circ} \mathrm{C}+\right.$ for $10 \mathrm{~s}$ for 80 cycles). All PCR reactions were performed in triplicate and included negative controls (no DNA) as well as positive controls (serial dilutions of known amounts of genomic DNA).

Target DNA sequence quantities were estimated from threshold amplification cycle numbers $\left(\mathrm{T}_{\mathrm{c}}\right)$ using iCycler software. For every gene sequence studied, a $\Delta \mathrm{T}_{c}$ value was calculated for each sample by subtracting the $\mathrm{T}_{c}$ value for the immunoprecipitated sample from the $\mathrm{T}_{\mathrm{c}}$ value for the corresponding Input DNA to normalize for differences in ChIP sample aliquots before immunoprecipitation. DNA quantities were then expressed as percentages of corresponding Input using the following equation: (antibody ChIP as a percentage of Input) $=2\left(\Delta \mathrm{T}_{\mathrm{c}}\right) \times 100$. Finally, DNA quantities (normalized to Input) were compared for immunoprecipitated versus mock-immunoprecipitated samples; only when immunoprecipitated samples contained $>1.5$ times as much DNA were they considered to have sufficient DNA for analysis.

Input and IP samples were interrogated with gene promoter-specific primers in triplicate reactions in real-time PCR analysis as described previously (Braveman et al., 2004; Chen-Plotkin et al., 2006; Sadri-Vakili et al., 2007). Threshold amplification cycle numbers $\left(T_{c}\right)$ using iCycler software were used to calculate IP DNA quantities as percentage of corresponding inputs. The following exon-specific BDNF primers were designed based on previously published sequences (Chen et al., 2003; Martinowich et al., 2003; Jiang et al., 2008) and used for real-time PCR analysis: BDNF exon I, forward, 5'-GCAGTTGGACAG TCATTGGTAACC-3'; reverse, 5' -ACGCAAACGCCCTCATTCTG-3'; BDNF exon II (a, b, c), forward, 5'-GCAGAGTCCATTCAGCACCTTG-3'; reverse, 5' -TGGCTTGACAGCGAGGAAAAG-3'; BDNF exon IV (CREB and MeCP2 binding sites), forward, 5' -AACAAGAGGCTGTGACACTATGCTC-3'; reverse, $5^{\prime}$-CAGTAAGTAAAGGCTAGGGCAGGC-3'; forward, 5'-AAAGCATGCAATGCCCT-3; reverse, 5'-GAGATTTCATGCTAGCTCGC-3'; forward, 5'-GGCTTCTGTGTGCGTGAATTTGC-3'; reverse, 5'-AAAGTGGGTGGGAGTCCACGAG-3'; BDNF exon IV, forward, 5' -TTTGGGGCAGACGAGAAAGC- $3^{\prime}$; reverse, $5^{\prime}$-GGCAGTGGAGTCACATTGTTGTC- $3^{\prime}$.

DNA quantitation. ChIP products were quantified using the luciferasebased and T4 DNA polymerase-based DNA Quantitation System (Promega) according to the instructions of the manufacturer. The light output was immediately measured in a luminometer (TD-20/20 Luminometer; Turner Designs). ChIP products were also quantified using Quant-iT PicoGreen dsDNA reagent (Invitrogen) and assayed on the Wallac Victor 1420 Multilabel Counter (PerkinElmer Life and Analytical Sciences) with excitation and emission wavelengths of 485 and $535 \mathrm{~nm}$, respectively.

RNA extraction and reverse transcription. RNA was extracted from dissected brain regions from one hemisphere of cocaine or yoked rats using RNeasy kit (Qiagen) according to the instructions of the manufacturer and as described previously (Sadri-Vakili et al., 2007). Reverse transcription (RT) reactions were performed using the Superscript First Strand Synthesis System for 
RT-PCR reactions (Invitrogen) using specific primers to quantitate the amount of gene expression compared with a standard curve. The following primers were used for real-time PCR to quantitate the amount of gene expression. The exon-specific BDNF primers were designed based on previously published results (Nakayama et al., 1994; Chen et al., 2003; Martinowich et al., 2003: Jiang et al., 2008). BDNF exon I, forward, 5 '-AAGCCGAACTTCTCACATGATGA-3'; reverse, 5'-TGCAACCGAAGTATGAAATAACCATAG$3^{\prime}$; BDNF exon II (a, b, c), forward, 5'-GCAGAGTCCATTCAGCACCTT G-3'; reverse, 5'-TGGCTTGACAGCGAGGAAAAG-3'; BDNF exon IV, forward, 5' -CTGCCTAGATCAAATGGAGCTTCT-3'; reverse, 5' -GGAAATTGCATGGCGGAGGTAA-3'; BDNF exon IV, forward, 5' -TTTGGGGCAGACGAGAAAGC-3'; reverse, 5'-GGCAGTGGAGTCACATTGTTGTC-3'; CB1, forward, 5'-CCTCTACGTGGGCTCAAATG-3'; reverse, 5'-GGAAGGGACTACCCCTGAAG-3'; DRD2, forward, 5'-GGTCTGCAAAGCCTTCTCTC-3'; reverse, 5'-TACTATGCCATGCTGCTCAC-3'; glyceraldehyde-3-phosphate dehydrogenase (GAPDH), forward, $5^{\prime}$-AACAGCAACTCCCATTC TTC-3'; reverse, 5'-TGGTCCAGGGTTTCTTACTC-3'; GluR1, forward, 5' -ATGCTGACCTCCTTCTGTGG-3'; reverse, 5' -TCCTGTAGTTCCGGGCGTAG-3'; GluR2, forward, 5'-ATTTCGGGTAGGGATGGTTC-3'; reverse, 5'-GCGAAACTGTTGGCTACCTC; mGluR5, forward, $5^{\prime}$-GCACAGTCCAGTGAGAGGAG-3' ; reverse, 5' $^{\prime}$-TTGTCCACAGTTGGTTGGTG-3'; NR1, forward, 5'-TAGTTAGCCACCCGCCTAC-3'; reverse, 5'-GACATTCGGGTAGTCAGTCC-3'; preprodynorphin, forward, 5'-CTGCACACAGGGAACACAAG-3'; reverse 5'-TGATACAGAATGGCGTGGTC; preproenkephalin, forward, 5'-GCTTGGGTGTTCTGCTTCTC-3'; reverse, 5' -TCCAGGGTTCT TAGTGCTGG-3'; SAP97, forward, 5'-ACCCGTGGACATTCTCAATC-3'; reverse, 5' -CGGTATCAGGACGAAGAGG-3'. Quantitative real-time PCR was performed in an iCycler (BioRad) with the use of SYBR green PCR Master Mix (Applied Biosystems) through $50 \mathrm{PCR}$ cycles $\left(95^{\circ} \mathrm{C}\right.$ for $30 \mathrm{~s}, 57^{\circ} \mathrm{C}$ for $60 \mathrm{~s}, 72^{\circ} \mathrm{C}$ for $\left.90 \mathrm{~s}\right)$. The threshold cycle for each sample was chosen from the linear range and converted to a starting quantity by interpolation from a standard curve run on the same plate for each set of primers. The mRNA levels were normalized for each well to the GAPDH mRNA levels. Single PCR products were verified by assessing that the melting temperature of the product had a single value.

\section{Results}

Cocaine self-administration increases BDNF protein levels in the mPFC

After $14 \mathrm{~d}$ of cocaine self-administration and $7 \mathrm{~d}$ of forced abstinence, the animals were killed and the $\mathrm{MPFC}$ was removed. Figure $1 A$ is a diagram depicting a coronal section of the rat brain at the level of the mPFC (3.20 mm anterior to bregma) (Paxinos and Watson, 1997). The mPFC dissection (shown in black) included the anterior cingulate, prelimbic, and infralimbic cortices. There was a significant increase in BDNF protein levels in the mPFC (relative to yoked saline controls) as measured by Western blot analysis $\left[t_{(6)}=3.753, p<0.0095\right.$ (Fig. $\left.\left.1 B\right)\right]$ and ELISA $\left[t_{(5)}=\right.$ 6.727, $p<0.0011$ (Fig. 1C)].

\section{Decreasing BDNF in the mPFC enhances the reinforcing efficacy of cocaine}

To assess whether this cocaine-induced increase in BDNF levels in the $\mathrm{mPFC}$ has functional consequences, we used a viral vector to deliver interfering RNA to the mPFC to suppress BDNF mRNA levels. In initial experiments, adeno-associated viral vectors (AAV10) encoding EGFP together with shRNA targeting BDNF exon IX, which is common to all BDNF transcripts, or a scrambled sequence that is not found in any known mRNA (scrambled control) were microinjected into the mPFC using stereotaxic surgery. Ten days after treatment with AAV10-BDNF shRNA, there was an $~ 58 \%$ decrease in BDNF staining intensity per cell in the mPFC as measured by immunohistochemistry (Fig. $2)$, which was statistically significant $\left(t_{(5)}=3.683, p<0.0142\right)$. Six rats were used in this control experiment, and a total of 380 cells from the control side were compared with 231 cells from


Figure 1. BDNF protein levels are increased in the mPFC after cocaine self-administration. $\boldsymbol{A}$, A diagram depicting a coronal section of the rat brain at the level of the $\mathrm{MPFC}(3.20 \mathrm{~mm}$ anterior to bregma) (Paxinos and Watson, 1997). The MPFC dissection (shown in black) included the anterior cingulate, prelimbic, and infralimbic cortices. $\boldsymbol{B}$. Western blot analysis revealed an increase in BDNF protein levels in $\mathrm{MPFC}$. Densitometry results demonstrate a significant increase in BDNF levels in mPFC (saline, $n=4$; cocaine, $n=4$ ). C, Similarly, an ELISA demonstrated a significant increase in BDNF levels in the $\mathrm{mPFC}$ (saline, $n=4$; cocaine, $n=4$ ). IDV, Integrated density value. ${ }^{*} p<0.05$, significant differences between saline and cocaine treatments (unpaired $t$ tests,).

AAV10-BDNF shRNA-treated mPFC in these animals. The reduction in BDNF levels persisted for at least 3 weeks (data not shown). Although precise quantification of immunohistochemistry is problematic, these data indicate that there was extensive transfection of the AAV10-BDNF shRNA in the mPFC that clearly suppressed BDNF expression. However, it is acknowledged that the $58 \%$ reduction cited above is an estimate rather than an absolute quantification of BDNF knockdown by the shRNA. The decrease in BDNF after shRNA treatment was specific for BDNF because there was no change in neurotrophin-3 or microtubule-associated protein 2 levels in the treated animals (data not shown).

In a group of naïve rats, cocaine self-administration commenced 10-14 d after AAV10-BDNF shRNA administration into the mPFC. Importantly, all rats were within the same weight range (300-325 g) at the onset and throughout cocaine selfadministration. Approximately equal numbers of rats were administered control vectors (AAV10 encoding EGFP and AAV10 

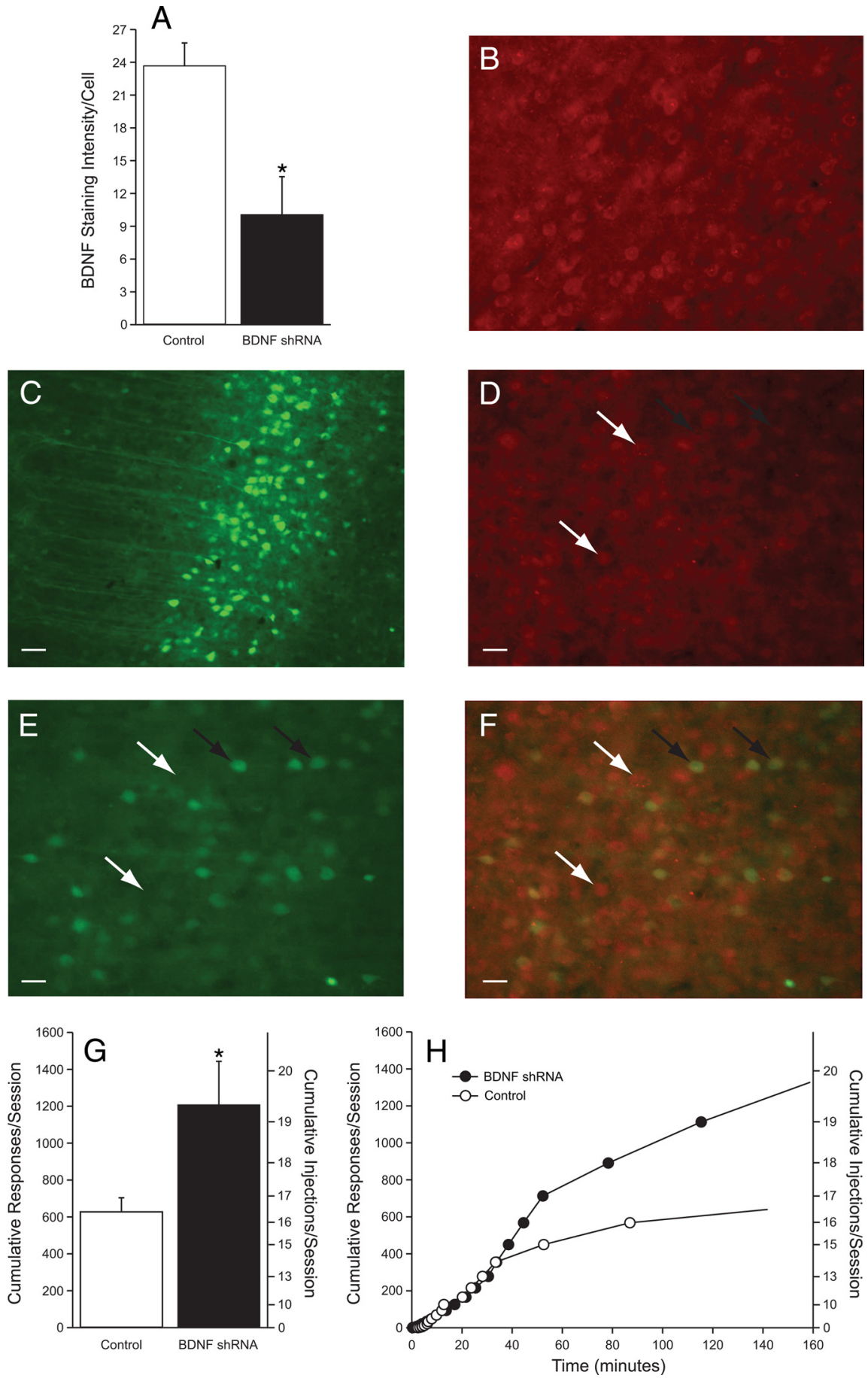

Figure 2. shRNA-induced downregulation of BDNF expression in the MPFC enhances the reinforcing efficacy of cocaine, as assessed with a PR schedule. $A$, The mean \pm SEM BDNF staining intensity per cell (in arbitrary units) in control and AAV10-BDNF shRNA-treated rats. A total of 380 cells were sampled in the control sections and 231 cells from AAV10 -BDNF shRNA-treated mPFC. Results indicate that BDNF shRNA produced a 58\% reduction in BDNF staining intensity per cell, which was a statistically significant decrease (unpaired $t$ test, $p<0.05$ ) (scrambled, $n=3$; shRNA, $n=3$ ). $\boldsymbol{B}$, Photomicrograph from the $\mathrm{mPFC}$ of a control subject. $C$, Lower magnification of EGFP labeling in the MPFC of an AAV10 -BDNF shRNA-treated rat. Scale bar, $100 \mu \mathrm{m}$. $\boldsymbol{D}-\boldsymbol{F}$ depict a subset of cells from $\boldsymbol{B}$. Shown are BDNF labeling $(\boldsymbol{D})$, EGFP expression $(\boldsymbol{E})$, as well as superimposed BDNF and EGFP $(\boldsymbol{F})$. Scale bars, $50 \mu \mathrm{m}$. The black arrows point to cells that express EGFP and have low BDNF labeling. In contrast, the white arrows point to cells that do not express EGFP and have higher BDNF expression. $\mathbf{G}$, The mean \pm SEM breakpoint, as defined by the cumulative responses and injections per session under the PR schedule for control and BDNF siRNA treatments. ${ }^{*} p<0.05$, significant difference between these groups (unpaired $t$ test). $\boldsymbol{H}$, Time course of cocaine self-administration from representative control and BDNF shRNA-treated subjects. There were seven subjects per treatment in the behavioral experiment. encoding EGFP plus a scrambled AAV shRNA). The behavioral data from these treatments did not differ significantly; therefore, these treatments were combined into a single control group. Rats initially were allowed to self-administer cocaine under an FR schedule of reinforcement with no previous training of any sort or food restriction. Results indicated no significant differences in the rate of acquisition or number of cocaine infusions per session between the BDNF shRNA and control virus-treated groups (data not shown). After $12 \mathrm{~d}$ of cocaine self-administration under the FR schedule of reinforcement, the reinforcing efficacy of cocaine was assessed using a PR schedule. Under the PR schedule, the breakpoint of AAV10-BDNF shRNA-treated rats was significantly higher than the control rats $\left(t_{(12)}=2.323, p<0.0385\right.$ ) (Fig. $2 G)$. There were seven subjects per treatment. The time courses for two representative subjects responding under the PR schedule are shown in Figure $2 H$. The breakpoints (cumulative responses per session) for each control subject were 685 , 563, 417, 647, 882, 871, 341; breakpoints for the shRNA subjects were 567, 1064, $1328,1533,1645,267,2066$. These results indicate that rats administered BDNF shRNA work substantially harder than control subjects to receive cocaine, which indicates that the reinforcing efficacy of cocaine is increased when BDNF in the $\mathrm{mPFC}$ is decreased.

\section{Cocaine self-administration selectively increases the expression of BDNF exon IV in the MPFC}

The rat BDNF gene contains multiple promoters that are used to generate mRNAs (Timmusk et al., 1993; Liu et al., 2006; Aid et al., 2007). There are eight untranslated 5' exons that are spliced onto the coding $3^{\prime}$ exon containing the coding domain for the BDNF protein. The different function of these transcripts is not known, but they are differentially targeted and translated within cells. We next assessed BDNF exon I, II, IV, and VI transcripts in the mPFC of cocaine-experienced rats (and yoked saline controls) after $7 \mathrm{~d}$ of forced abstinence. There was no expression of BDNF exon II mRNA in the mPFC. These data were analyzed with two-way ANOVA, which revealed significant main effects of drug treatment $\left(F_{(1,39)}=4.19, p<0.0473\right)$ and exon $\left(F_{(3,39)}=3.53, p<0.0234\right)$. Although the treatment $X$ exon interaction was not significant, a planned comparison using Tukey's honestly significant difference (HSD) test (which adequately con- 


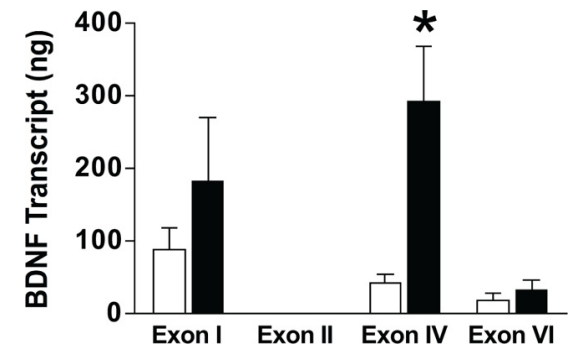

Figure 3. Cocaine self-administration selectively increases BDNF exon IV mRNA in the mPFC. BDNF exon I, II, IV, and VI transcripts were assessed in the MPFC of cocaine self-administration rats and yoked saline controls. There was no BDNF exon II expression in the mPFC. ${ }^{*} p<0.05$, significant increase in BDNF exon IV-containing transcript $7 \mathrm{~d}$ after cocaine self-administration relative to the saline control group (saline, $n=4$; cocaine, $n=8$ ) (Tukey's HSD test).

trols for the familywise error rate of the entire dataset) indicated a significant difference between the cocaine and saline groups for exon IV (Fig. 3). There were no other significant differences between cocaine- and saline-treated subjects. There were eight cocaine self-administration rats and four yoked saline controls analyzed for each exon in this experiment.

Increased association of acetylated histone $\mathrm{H} 3$ with BDNF gene after cocaine self-administration

Chromatin remodeling through modification of histone proteins is a requisite mechanism of gene expression. In general, histone acetylation corresponds to increased transcription, which is a possible mechanism underlying cocaine-induced increases in BDNF expression in the mPFC. To test this hypothesis, we used $\mathrm{ChIP}$ to assess the association of $\mathrm{AcH} 3$ with $\mathrm{BDNF}$ promoters in the mPFC. As shown in Figure 4, $A$ and $B$, Western blotting indicated that there was no change in overall levels of $\mathrm{AcH} 3$ in the mPFC. However, ChIP assays revealed that there was an increase in the association of $\mathrm{AcH} 3$ with BDNF promoter IV in the $\mathrm{mPFC}$ after cocaine self-administration (Fig. 4C). These data were analyzed with a two-way ANOVA, which revealed significant main effects of treatment (cocaine or saline) $\left(F_{(1,29)}=5.59, p<0.025\right)$, exon $\left(F_{(3,29)}=12.84 p<0.0001\right)$, as well as a significant treatment $X$ exon interaction $\left(F_{(3,29)}=6.12, p<0.0023\right)$. Subsequently, pairwise comparisons (Tukey's HSD test) showed that there was a significant difference between treatments only for exon IV (saline, $n=5$; cocaine, $n=4$ ). This finding suggests that cocaine self-administration followed by $7 \mathrm{~d}$ of forced abstinence results in enhanced association of acetylated $\mathrm{H} 3$ with BDNF exon IV in the mPFC.

Acetylated $\mathrm{H} 3$ promotes an open chromatin configuration, which allows for sequence-specific binding of transcription factors to promoter regions and influences gene expression. It is likely, therefore, that cocaine-induced increases in BDNF mRNA in the $\mathrm{MPFC}$ results from alterations in the assembly of transcription factors at BDNF promoters. BDNF gene expression is regulated by a number of transcription factors, including CREB and MeCP2 (West et al., 2001; Chen et al., 2003; Martinowich et al., 2003). Therefore, we next measured changes in pCREB (the active form of CREB) and MeCP2 after cocaine self-administration and $7 \mathrm{~d}$ of forced abstinence.

Cocaine self-administration increased the association of pCREB with BDNF exon IV in the MPFC

As shown in Figure 5, $A$ and $B$, Western blotting indicated no difference in global pCREB levels between animals allowed to self-administer cocaine and yoked saline controls. However,
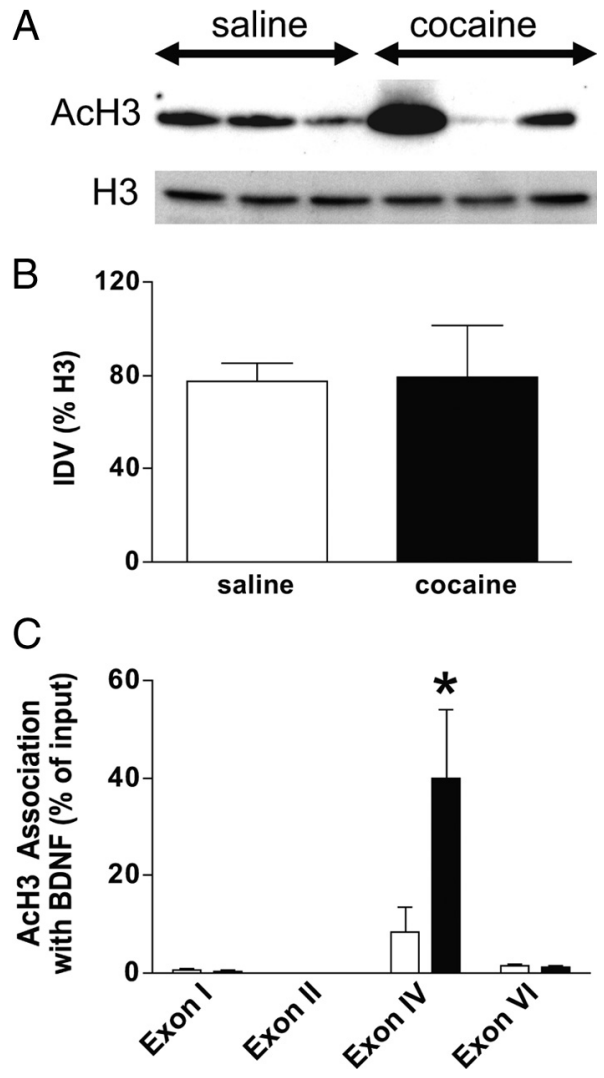

Figure 4. Increased association of acetylated histone $\mathrm{H} 3$ with BDNF exon IV in $\mathrm{mPFC}$ after cocaine self-administration. $\boldsymbol{A}$, Western blots of global $\mathrm{ACH} 3$ or $\mathrm{H} 3$ levels in cocaine selfadministration and yoked saline control subjects. $\boldsymbol{B}$, Analysis of densitometry values of $\mathrm{AcH} 3$ blots demonstrates that there is no significant change in global AcH3 levels (saline, $n=3$; cocaine, $n=3$ ). IDV, Integrated density value. $C$, In contrast, there was a significant increase in $\mathrm{AcH} 3$ association with BDNF exon IV promoter in the mPFC of cocaine relative to saline subjects as measured by ChIP (saline, $n=5$; cocaine, $n=4$ ) (Tukey's HSD test, ${ }^{*} p<0.05$ ).

global pCREB levels do not reflect what happens at individual gene promoters. Therefore, we measured changes in PCREB association with BDNF gene promoters using ChIP. After cocaine self-administration and $7 \mathrm{~d}$ of forced abstinence, there was an increase in $\mathrm{pCREB}$ association with BDNF promoter IV, but not with promoters I, II, or VI, in the mPFC (Fig. $5 C$ ). These data were analyzed with a two-way ANOVA, which indicated significant main effects of treatment $\left(F_{(1,31)}=5.51, p<0.0255\right)$ and exon $\left(F_{(3,31)}=9.28, p<0.0002\right)$, as well as a significant treatment $\times$ exon interaction $\left(F_{(3,31)}=4.02, p<0.0159\right)$. Subsequent pairwise comparisons (Tukey's HSD test, $p<0.05$ ) showed a significant difference between treatments for exon IV (saline, $n=$ 9; cocaine, $n=5$ ). These results indicate that one mechanism whereby cocaine increases BDNF expression is by specifically increasing the association of $\mathrm{pCREB}$ with BDNF promoter IV.

\section{Cocaine self-administration decreases MeCP2 association} with BDNF exon IV in the mPFC

$\mathrm{MeCP} 2$ repression of BDNF promoter IV has been well described in previous studies (Chen et al., 2003; Martinowich et al., 2003). A requisite step in BDNF promoter IV-containing gene expression is de-repression caused by the dissociation of MeCP2 from promoter IV (Chen et al., 2003). Although there was no global difference in MeCP2 levels in the mPFC (Fig. 6A,B), there was a decrease in MeCP2 association with BDNF promoter IV after cocaine self-administration with $7 \mathrm{~d}$ of forced abstinence in the 

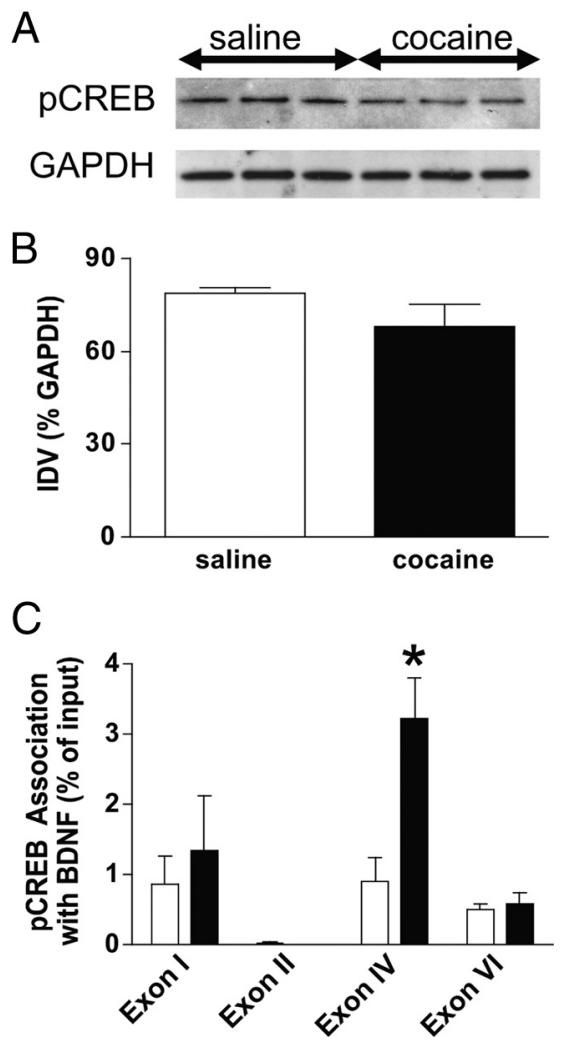

Figure 5. Cocaine self-administration results in increased association of $p C R E B$ with BDNF exon IV in the mPFC. $\boldsymbol{A}$, Western blots showing total pCREB and GAPDH levels in the MPFC. $\boldsymbol{B}$, Analysis of the Western blot quantification showed no significant change in pCREB levels in $\mathrm{mPFC}$ in cocaine self-administration relative to saline controls (saline, $n=3$; cocaine, $n=3$ ). IDV, Integrated density value. C, However, ChIP analyses showed that there was a significant increase in the association of $p C R E B$ with BDNF promoter IV in the $\mathrm{MPFC}$ in the cocaine relative to the saline group (saline, $n=9$; cocaine, $n=5$ ) (Tukey's HSD test, ${ }^{*} p<0.05$ ).

mPFC (Fig. 6C), whereas MeCP2 association with other BDNF promoters was unchanged. These data were analyzed with a twoway ANOVA, which indicated significant main effects of treatment $\left(F_{(1,31)}=5.32, p<0.0279\right)$ and exon $\left(F_{(3,31)}=9.24, p<\right.$ 0.0002). Although the treatment $\times$ exon interaction did not reach statistical significance $\left(F_{(3,31)}=2.61, p<0.069\right)$, planned pairwise comparisons using Tukey's HSD test $(p<0.05)$, which accounts for the familywise error rate of the overall ANOVA, showed a significant difference between treatments for exon IV (saline, $n=5$; cocaine, $n=5$ ). These data indicate that decreased association of MeCP2 with BDNF exon IV, resulting in derepression, contributes to cocaine-induced increases in BDNF transcription in the mPFC.

Given that MeCP2 binds to methylated cytosines, there is a possibility that the dissociation of $\mathrm{MeCP} 2$ from $\mathrm{BDNF}$ promoter IV is attributable to a decrease in DNA methylation in response to cocaine self-administration. To assess this effect, we measured methylated DNA levels using ChIP with an antibody specific for 5 -methyl-cytosine followed by DNA quantitation. Although both saline and cocaine groups yielded higher levels of DNA compared with the control no antibody mock sample, a $t$ test revealed no difference in the amount of DNA that was precipitated in the saline $(0.9125 \pm 0.4303, n=4)$ versus the cocaine group $(0.4250 \pm 0.08539, n=4)$, suggesting that that the dissociation of $\mathrm{MeCP} 2$ from $\mathrm{BDNF}$ promoter IV is not attributable to changes in DNA methylation.
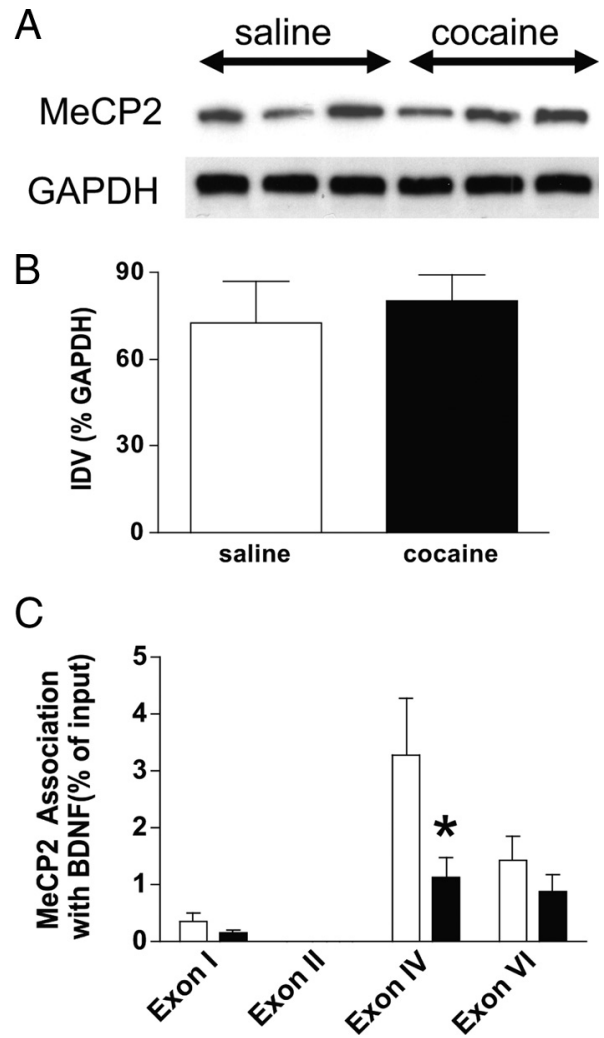

Figure 6. Decreased association of MeCP2 with BDNF exon IV in the MPFC after cocaine self-administration. $A$, Western blots showing total MeCP2 and GAPDH levels in the MPFC of control and cocaine self-administration rats. $\boldsymbol{B}$, Analysis of the Western blot densitometry revealed no significant difference between groups for MeCP2 levels in $\mathrm{mPFC}$ (saline, $n=3$; cocaine, $n=3)$. IDV, Integrated density value. $C$, In contrast, there was a significant decrease in the association of MeCP2 with BDNF promoter IV in the $\mathrm{MPFC}$ of cocaine versus saline-treated subjects (saline, $n=5$; cocaine, $n=5$ ) (Tukey's HSD test, ${ }^{*} p<0.05$ ).

\section{Discussion}

In the current study, cocaine self-administration followed by $7 \mathrm{~d}$ of forced abstinence increased BDNF mRNA and protein levels in the rat mPFC. Furthermore, decreasing BDNF levels using RNA interference enhanced cocaine self-administration under a PR schedule, suggesting that increased mPFC BDNF levels counteract the reinforcing efficacy of cocaine. Examination of specific BDNF exons revealed that cocaine self-administration selectively increased BDNF exon IV in the mPFC. Cocaine self-administration increased the association of acetylated histone $\mathrm{H} 3$ with $\mathrm{mPFC}$ BDNF promoter IV, which confers an open chromatin confirmation. Increased pCREB and decreased $\mathrm{MeCP} 2$ association with mPFC BDNF promoter IV also were observed after cocaine selfadministration and $7 \mathrm{~d}$ of forced abstinence. Thus, the molecular mechanisms underlying the functionally relevant increase in $\mathrm{BDNF}$ expression in the $\mathrm{mPFC}$ induced by previous cocaine self-administration appear to focus at least in part on CREBinduced promotion and $\mathrm{MeCP} 2$-mediated de-repression of BDNF transcription.

\section{Cocaine-induced changes in gene expression}

Previous studies have shown that alterations in gene expression underlie cocaine-induced neuronal and behavioral plasticity (Nestler et al., 1996; Nestler, 2004). Both acute and repeated cocaine administration result in transient changes in gene expression in a number of brain regions (Yuferov et al., 2005). The cocaine-induced genes encode for neurotransmitter receptors, 
transporters, transcription factors, neuropeptides, and molecules involved in calcium signaling (Freeman et al., 2001; Backes and Hemby, 2003; Tang et al., 2003; Yuferov et al., 2005). Here, after $14 \mathrm{~d}$ of self-administration and $7 \mathrm{~d}$ of forced abstinence, we observed a specific increase in BDNF exon IV-containing transcript in the $\mathrm{mPFC}$. Previous work indicates that cocaine self-administration also increases BDNF expression in the VTA (Grimm et al., 2003). In addition, studies have shown that both acute and repeated injections of cocaine have been shown to influence the expression of BDNF in dopaminoreceptive limbic nuclei. Thus, an acute injection of cocaine increases BDNF mRNA in the striatum, $\mathrm{mPFC}$, and nucleus accumbens (Le Foll et al., 2005; Liu et al., 2006). Likewise, a sensitizing regimen of cocaine injections or cocaine self-administration results in increased BDNF mRNA in the mPFC, nucleus accumbens, and striatum (Le Foll et al., 2002; Zhang et al., 2002; Kumar et al., 2005; Fumagalli et al., 2007).

\section{Behavioral consequences of cocaine-induced changes in BDNF transcription}

Several studies have shown that BDNF influences cocaine reward, reinforcement, and the reinstatement of cocaine seeking. Thus, BDNF knock-out mice have deficits in the ability to express conditioned place preference to cocaine (Hall et al., 2003), indicating that BDNF plays an important role in conditioned cocaine reward. Similarly, inducible knock-out of BDNF in nucleus accumbens neurons reduced cocaine reinforcement, as assessed with cocaine self-administration under a fixed ratio schedule (Graham et al., 2007). BDNF also has been shown to influence the reinstatement of cocaine seeking, an animal model of craving and relapse (Shalev et al., 2002). The enhancement (or "incubation") of cue-induced cocaine seeking with time following the extinction of cocaine self-administration is paralleled by increases in BDNF protein levels in the VTA, nucleus accumbens, and amygdala (Grimm et al., 2003). Moreover, a single infusion of BDNF into the VTA enhanced the reinstatement of cocaine seeking (Lu et al., 2004). Repeated administration of BDNF into the nucleus accumbens also results in enduring enhancement of the reinstatement of cocaine seeking (Graham et al., 2007). Together, these findings indicate that BDNF in several key nuclei contributes significantly to cocaine reinforcement and the reinstatement of cocaine seeking.

Among human cocaine addicts as well as in animals allowed to chronically self-administer cocaine, there are decreases in $\mathrm{D}_{2}$ dopamine receptor expression in the nucleus accumbens (Volkow et al., 1999; Nader and Czoty, 2005), which may prompt further cocaine intake to compensate for this deficit (Volkow et al., 1999). The present results demonstrate a similar homeostatic mechanism consistent with the opponent-process view of addiction (Solomon and Corbit, 1974). Thus, decreasing BDNF in the $\mathrm{mPFC}$ increased the self-administration of cocaine, suggesting that cocaine-induced increases in $\mathrm{MPFC} B D N F$ transcription is a compensatory reaction to decrease the reinforcing efficacy of cocaine. Because animals and humans allowed repeated access to cocaine ultimately develop robust and persistent patterns of cocaine self-administration, other changes in the limbic system must override the homeostatic plasticity associated with BDNF in the $\mathrm{mPFC}$. Conversely, our results suggest that increasing BDNF expression in the MPFC may diminish the reinforcing efficacy of cocaine. Consistent with this notion, recent evidence indicates that exogenous BDNF infusions into the $\mathrm{mPFC}$ suppress the reinstatement of cocaine seeking (Berglind et al., 2007) by normalizing cocaine-induced alterations in glutamate transmission in the nucleus accumbens (Berglind et al., 2009; McGinty et al., 2010).

\section{Mechanisms underlying cocaine-induced changes in BDNF transcription}

Several recent studies have demonstrated that chromatin remodeling is an important mechanism underlying cocaine-induced alterations in gene expression. Specifically, cocaine hyperacetylates histone $\mathrm{H} 3$ and $\mathrm{H} 4$ associated with gene promoters (BramiCherrier et al., 2005; Kumar et al., 2005; Levine et al., 2005; Black et al., 2006; Cassel et al., 2006; Renthal et al., 2007; Schroeder et al., 2007; Freeman et al., 2008). Specifically, there is hyperacetylation of histone $\mathrm{H} 3$ at BDNF promoters after chronic cocaine administration (Kumar et al., 2005). Indeed, chronic cocaine exposure decreases histone deacetylase (HDAC) function in the nucleus accumbens, and the loss of HDAC5 enhances the behavioral response induced by chronic cocaine (Renthal et al., 2007). In addition, it was shown that administration of an HDAC inhibitor significantly reduced the breakpoint for cocaine under a PR schedule, which correlated with measurements of HDAC activity in the frontal cortex (Romieu et al., 2008). This behavioral finding is consistent with the current results, which revealed that increased histone $\mathrm{H} 3$ acetylation in the $\mathrm{MPFC}$ specifically associated with BDNF exon IV enhanced the cocaine breakpoint. Collectively, these results indicate that repeated exposure to cocaine results in the acetylation of histones in specific brain regions, including the mPFC, resulting in an active chromatin confirmation, which allows for sequence-specific transcription factor binding to promoter regions.

Numerous studies have demonstrated that the repeated intake of drugs of abuse increases protein kinase A activity, thereby increasing phosphorylation of the transcription factor CREB, which leads to CREB-mediated transcription of genes, including BDNF (Turgeon et al., 1997; Shaw-Lutchman et al., 2002; Carlezon et al., 2005). For example, acute exposure to cocaine results in the recruitment of CREB-binding protein to the fosB promoter to acetylate $\mathrm{H} 4$ (Levine et al., 2005). The present results showed a significant increase in pCREB association with BDNF exon IV after cocaine self-administration, which suggests that cocaineinduced hyperacetylation at histone $\mathrm{H} 3$ allows pCREB to promote BDNF expression by interacting specifically with exon IV.

The rat BDNF exon IV promoter contains eight CpG sites that serve as binding domains for MeCP2 (Martinowich et al., 2003). $\mathrm{MeCP} 2$ has been shown to repress BDNF promoter IV expression in the absence of neuronal activity (Chen et al., 2003). MeCP2 silencing of the BDNF gene may occur through chromatin remodeling given that $\mathrm{MeCP} 2$ has been shown to recruit histone deacetylases, co-repressors, and histone methyltransferases (Chen et al., 2003; Martinowich et al., 2003). A prerequisite step in BDNF promoter IV-containing gene expression is de-repression caused by the dissociation of MeCP2 from promoter IV (Chen et al., 2003). The current findings indicated that there was no change in overall levels of $\mathrm{MeCP} 2$ in response to cocaine self-administration, which contrasts with a report of increased MeCP2 in response to cocaine (Cassel et al., 2006). It should be noted, however, that in the previous study, animals were treated with daily cocaine injections for $10 \mathrm{~d}$ with no withdrawal period (Cassel et al., 2006), whereas in the present study, rats self-administered cocaine for $14 \mathrm{~d}$ and $\mathrm{MeCP} 2$ levels were measured after $7 \mathrm{~d}$ of forced drug abstinence. We also demonstrated that cocaine self-administration resulted in decreased association of MeCP2 with BDNF promoter IV that was not attributable to changes in DNA methylation at this promoter. Thus, the current data suggest that cocaine-induced increases in $\mathrm{BDNF}$ expression in the $\mathrm{mPFC}$ are partially attributable to derepression of BDNF transcription via the dissociation of MeCP2 from the exon IV promoter. 


\section{Conclusions}

The present findings indicate that cocaine self-administration increases BDNF expression in the mPFC. This cocaine-induced increase in BDNF in the $\mathrm{mPFC}$ appears to represent a homeostatic neuroadaptation that acts to decrease the reinforcing efficacy of cocaine. The current results also define a series of molecularly precise mechanisms whereby cocaine self-administration increases $\mathrm{mPFC}$ BDNF transcription, including enhanced association of $\mathrm{AcH} 3$ and pCREB with BDNF exon IV as well as decreased association of MeCP2 with this BDNF promoter. Delineating novel and specific molecular consequences of cocaine self-administration such as these may lead to novel avenues for the development of treatments for cocaine craving and addiction.

\section{References}

Aid T, Kazantseva A, Piirsoo M, Palm K, Timmusk T (2007) Mouse and rat BDNF gene structure and expression revisited. J Neurosci Res 85:525-535.

Backes E, Hemby SE (2003) Discrete cell gene profiling of ventral tegmental dopamine neurons after acute and chronic cocaine self-administration. J Pharmacol Exp Ther 307:450-459.

Berglind WJ, See RE, Fuchs RA, Ghee SM, Whitfield TW Jr, Miller SW, McGinty JF (2007) A BDNF infusion into the medial prefrontal cortex suppresses cocaine seeking in rats. Eur J Neurosci 26:757-766.

Berglind WJ, Whitfield TW Jr, LaLumiere RT, Kalivas PW, McGinty JF (2009) A single intra-PFC infusion of BDNF prevents cocaine-induced alterations in extracellular glutamate within the nucleus accumbens. J Neurosci 29:3715-3719.

Black YD, Maclaren FR, Naydenov AV, Carlezon WA Jr, Baxter MG, Konradi C (2006) Altered attention and prefrontal cortex gene expression in rats after binge-like exposure to cocaine during adolescence. J Neurosci 26:9656-9665.

Brami-Cherrier K, Valjent E, Hervé D, Darragh J, Corvol JC, Pages C, Arthur SJ, Girault JA, Caboche J (2005) Parsing molecular and behavioral effects of cocaine in mitogen- and stress-activated protein kinase-1-deficient mice. J Neurosci [Erratum (2006) 26:table of contents] 25:11444-11454.

Braveman MW, Chen-Plotkin AS, Yohrling GJ, Cha JH (2004) Chromatin immunoprecipitation technique for study of transcriptional dysregulation in intact mouse brain. Methods Mol Biol 277:261-276.

Carlezon WA Jr, Duman RS, Nestler EJ (2005) The many faces of CREB. Trends Neurosci 28:436-445.

Cassel S, Carouge D, Gensburger C, Anglard P, Burgun C, Dietrich JB, Aunis D, Zwiller J (2006) Fluoxetine and cocaine induce the epigenetic factors MeCP2 and MBD1 in adult rat brain. Mol Pharmacol 70:487-492.

Chen WG, Chang Q, Lin Y, Meissner A, West AE, Griffith EC, Jaenisch R, Greenberg ME (2003) Derepression of BDNF transcription involves calcium-dependent phosphorylation of MeCP2. Science 302:885-889.

Chen-Plotkin AS, Sadri-Vakili G, Yohrling GJ, Braveman MW, Benn CL, Glajch KE, DiRocco DP, Farrell LA, Krainc D, Gines S, MacDonald ME, Cha JH (2006) Decreased association of the transcription factor Sp1 with genes downregulated in Huntington's disease. Neurobiol Dis 22:233-241.

Clark KR, Liu X, McGrath JP, Johnson PR (1999) Highly purified recombinant adeno-associated virus vectors are biologically active and free of detectable helper and wild-type viruses. Hum Gene Ther 10:1031-1039.

De BP, Heguy A, Hackett NR, Ferris B, Leopold PL, Lee J, Pierre L, Gao G, Wilson JM, Crystal RG (2006) High levels of persistent expression of alpha1-antitrypsin mediated by the nonhuman primate serotype rh. 10 adeno-associated virus despite preexisting immunity to common human adeno-associated viruses. Mol Ther 13:67-76.

Freeman WM, Brebner K, Lynch WJ, Robertson DJ, Roberts DC, Vrana KE (2001) Cocaine-responsive gene expression changes in rat hippocampus. Neuroscience 108:371-380.

Freeman WM, Patel KM, Brucklacher RM, Lull ME, Erwin M, Morgan D, Roberts DC, Vrana KE (2008) Persistent alterations in mesolimbic gene expression with abstinence from cocaine self-administration. Neuropsychopharmacology 33:1807-1817.

Fumagalli F, Di Pasquale L, Caffino L, Racagni G, Riva MA (2007) Repeated exposure to cocaine differently modulates BDNF mRNA and protein levels in rat striatum and prefrontal cortex. Eur J Neurosci 26:2756-2763.
Gao GP, Alvira MR, Wang L, Calcedo R, Johnston J, Wilson JM (2002) Novel adeno-associated viruses from rhesus monkeys as vectors for human gene therapy. Proc Natl Acad Sci U S A 99:11854-11859.

Graham DL, Edwards S, Bachtell RK, DiLeone RJ, Rios M, Self DW (2007) Dynamic BDNF activity in nucleus accumbens with cocaine use increases self-administration and relapse. Nat Neurosci 10:1029-1037.

Grimm JW, Lu L, Hayashi T, Hope BT, Su TP, Shaham Y (2003) Timedependent increases in brain-derived neurotrophic factor protein levels within the mesolimbic dopamine system after withdrawal from cocaine: implications for incubation of cocaine craving. J Neurosci 23:742-747.

Hall FS, Drgonova J, Goeb M, Uhl GR (2003) Reduced behavioral effects of cocaine in heterozygous brain-derived neurotrophic factor (BDNF) knockout mice. Neuropsychopharmacology 28:1485-1490.

Horger BA, Iyasere CA, Berhow MT, Messer CJ, Nestler EJ, Taylor JR (1999) Enhancement of locomotor activity and conditioned reward to cocaine by brain-derived neurotrophic factor. J Neurosci 19:4110-4122.

Jiang X, Tian F, Du Y, Copeland NG, Jenkins NA, Tessarollo L, Wu X, Pan H, Hu XZ, Xu K, Kenney H, Egan SE, Turley H, Harris AL, Marini AM, Lipsky RH (2008) BHLHB2 controls Bdnf promoter 4 activity and neuronal excitability. J Neurosci 28:1118-1130.

Kalivas PW (2005) How do we determine which drug-induced neuroplastic changes are important? Nat Neurosci 8:1440-1441.

Kumar A, Choi KH, Renthal W, Tsankova NM, Theobald DE, Truong HT, Russo SJ, Laplant Q, Sasaki TS, Whistler KN, Neve RL, SelfDW, Nestler EJ (2005) Chromatin remodeling is a key mechanism underlying cocaineinduced plasticity in striatum. Neuron 48:303-314.

Le Foll B, Francès H, Diaz J, Schwartz JC, Sokoloff P (2002) Role of the dopamine D3 receptor in reactivity to cocaine-associated cues in mice. Eur J Neurosci 15:2016-2026.

Le Foll B, Diaz J, Sokoloff P (2005) A single cocaine exposure increases BDNF and D3 receptor expression: implications for drug-conditioning. Neuroreport 16:175-178.

Levine AA, Guan Z, Barco A, Xu S, Kandel ER, Schwartz JH (2005) CREBbinding protein controls response to cocaine by acetylating histones at the fosB promoter in the mouse striatum. Proc Natl Acad Sci U S A 102:19186-19191.

Liu QR, Lu L, Zhu XG, Gong JP, Shaham Y, Uhl GR (2006) Rodent BDNF genes, novel promoters, novel splice variants, and regulation by cocaine. Brain Res 1067:1-12.

Lu L, Dempsey J, Liu SY, Bossert JM, Shaham Y (2004) A single infusion of brain-derived neurotrophic factor into the ventral tegmental area induces long-lasting potentiation of cocaine seeking after withdrawal. J Neurosci 24:1604-1611.

Martin-Iverson MT, Altar CA (1996) Spontaneous behaviours of rats are differentially affected by substantia nigra infusions of brain-derived neurotrophic factor and neurotrophin-3. Eur J Neurosci 8:1696-1706.

Martin-Iverson MT, Todd KG, Altar CA (1994) Brain-derived neurotrophic factor and neurotrophin-3 activate striatal dopamine and serotonin metabolism and related behaviors: interactions with amphetamine. J Neurosci 14:1262-1270.

Martinowich K, Hattori D, Wu H, Fouse S, He F, Hu Y, Fan G, Sun YE (2003) DNA methylation-related chromatin remodeling in activity-dependent BDNF gene regulation. Science 302:890-893.

McGinty JF, Whitfield TW Jr, Berglind WJ (2010) Brain-derived neurotrophic factor and cocaine addiction. Brain Res 1314:183-193.

Nader MA, Czoty PW (2005) PET imaging of dopamine D2 receptors in monkey models of cocaine abuse: genetic predisposition versus environmental modulation. Am J Psychiatry 162:1473-1482.

Nakayama M, Gahara Y, Kitamura T, Ohara O (1994) Distinctive four promoters collectively direct expression of brain-derived neurotrophic factor gene. Brain Res Mol Brain Res 21:206-218.

Nestler EJ (2004) Molecular mechanisms of drug addiction. Neuropharmacology 47 [Suppl 1]:24-32.

Nestler EJ (2005) Is there a common molecular pathway for addiction? Nat Neurosci 8:1445-1449.

Nestler EJ, Berhow MT, Brodkin ES (1996) Molecular mechanisms of drug addiction: adaptations in signal transduction pathways. Mol Psychiatry 1:190-199.

Paxinos G, Watson C (1997) The rat brain in stereotaxic coordinates. New York: Academic.

Pierce RC, Kumaresan V (2006) The mesolimbic dopamine system: The 
final common pathway for the reinforcing effect of drugs of abuse? Neurosci Biobehav Rev 30:215-238.

Pierce RC, Pierce-Bancroft AF, Prasad BM (1999) Neurotrophin-3 contributes to the initiation of behavioral sensitization to cocaine by activating the Ras/mitogen-activated protein kinase signal transduction cascade. J Neurosci 19:8685-8695.

Renthal W, Maze I, Krishnan V, Covington HE 3rd, Xiao G, Kumar A, Russo SJ, Graham A, Tsankova N, Kippin TE, Kerstetter KA, Neve RL, Haggarty SJ, McKinsey TA, Bassel-Duby R, Olson EN, Nestler EJ (2007) Histone deacetylase 5 epigenetically controls behavioral adaptations to chronic emotional stimuli. Neuron 56:517-529.

Richardson NR, Roberts DC (1996) Progressive ratio schedules in drug selfadministration studies in rats: a method to evaluate reinforcing efficacy. J Neurosci Methods 66:1-11.

Romieu P, Host L, Gobaille S, Sandner G, Aunis D, Zwiller J (2008) Histone deacetylase inhibitors decrease cocaine but not sucrose self-administration in rats. J Neurosci 28:9342-9348.

Sadri-Vakili G, Bouzou B, Benn CL, Kim MO, Chawla P, Overland RP, Glajch KE, Xia E, Qiu Z, Hersch SM, Clark TW, Yohrling GJ, Cha JH (2007) Histones associated with downregulated genes are hypo-acetylated in Huntington's disease models. Hum Mol Genet 16:1293-1306.

Schroeder FA, Lin CL, Crusio WE, Akbarian S (2007) Antidepressant-like effects of the histone deacetylase inhibitor, sodium butyrate, in the mouse. Biol Psychiatry 62:55-64.

Shaham Y, Hope BT (2005) The role of neuroadaptations in relapse to drug seeking. Nat Neurosci 8:1437-1439.

Shalev U, Grimm JW, Shaham Y (2002) Neurobiology of relapse to heroin and cocaine seeking: a review. Pharmacol Rev 54:1-42.

Shaw-Lutchman TZ, Barrot M, Wallace T, Gilden L, Zachariou V, Impey S, Duman RS, Storm D, Nestler EJ (2002) Regional and cellular mapping of cAMP response element-mediated transcription during naltrexoneprecipitated morphine withdrawal. J Neurosci 22:3663-3672.

Solomon RL, Corbit JD (1974) An opponent-process theory of motivation. I. Temporal dynamics of affect. Psychol Rev 81:119-145.

Tang WX, Fasulo WH, Mash DC, Hemby SE (2003) Molecular profiling of midbrain dopamine regions in cocaine overdose victims. J Neurochem 85:911-924.

Timmusk T, Palm K, Metsis M, Reintam T, Paalme V, Saarma M, Persson H (1993) Multiple promoters direct tissue-specific expression of the rat BDNF gene. Neuron 10:475-489.

Turgeon SM, Pollack AE, Fink JS (1997) Enhanced CREB phosphorylation and changes in c-Fos and FRA expression in striatum accompany amphetamine sensitization. Brain Res 749:120-126.

Volkow ND, Fowler JS, Wang GJ (1999) Imaging studies on the role of dopamine in cocaine reinforcement and addiction in humans. J Psychopharmacol 13:337-345.

West AE, Chen WG, Dalva MB, Dolmetsch RE, Kornhauser JM, Shaywitz AJ, Takasu MA, Tao X, Greenberg ME (2001) Calcium regulation of neuronal gene expression. Proc Natl Acad Sci U S A 98:11024-11031.

Wise RA (2004) Dopamine, learning and motivation. Nat Rev Neurosci 5:483-494.

Xiao X, Li J, Samulski RJ (1998) Production of high-titer recombinant adeno-associated virus vectors in the absence of helper adenovirus. J Virol 72:2224-2232.

Yuferov V, Nielsen D, Butelman E, Kreek MJ (2005) Microarray studies of psychostimulant-induced changes in gene expression. Addict Biol 10:101-118.

Zhang D, Zhang L, Lou DW, Nakabeppu Y, Zhang J, Xu M (2002) The dopamine D1 receptor is a critical mediator for cocaine-induced gene expression. J Neurochem 82:1453-1464. 